\title{
Adult Literacy and the Need for Post-Adult Literacy Institution in Nigeria
}

\author{
Naboth H. A. Nwafor; Ph.D. \\ Department of Educational Foundations \\ Rivers State University of Science and Technology \\ Port Harcourt \\ Comfort W. Agi; Ph.D. \\ Department of Educational Foundations \\ Rivers State University of Science and Technology \\ Rort Harcourt
Pors State University of Science and Technology
}

\section{Doi:10.5901/mjss.2013.v4n4p469}

\section{Abstract}

In the annals of the formal education system in Nigeria, adult literacy occupies a very prominent position, but this situation has radically changed over the years, hence the need to revitalize it. This paper gives a brief historical overview of Adult Literacy in Nigeria, it examines the concept of adult literacy, and outlines its components, and the rationale for adult literacy. It equally highlights the place of adult literacy in the National Policy on Education, and the impediments to the realisation of its goals. Finally, the paper stresses the need for Adult Literacy College, its problems and prospects, and makes some recommendations.

Key words: adult literacy, post adult literacy, functional literacy

\section{Introduction}

There has been an increasing awareness and emphasis on eradication of illiteracy since the adoption of the Universal Declaration of Human Rights on $10^{\text {th }}$ December, 1945 by the General Assembly of the United Nations. Article 26 of that document explicitly states that: "Everyone has the right to education" (Iwe, 1978). This statement is all inclusive - male and female, old and young. It implies that education is an inviolable right (and not a privilege) to be acquired and enjoyed by every citizen, irrespective of age, social status or sex. Education in this context therefore refers to formal education, which is rooted in literacy. The emphasis on education as a vehicle for socio-economic and political development vis-àvis the well-being of the individuals continued to receive global attention at different times. In this regard, the Jomtien Conference of 1990 attended by 155 countries and 150 organisations gave birth to the global slogan, "Education for All" (EFA). The attendees pledged to make education accessible to all by the year 2000 (UNESCO, 2003). Apparently, this goal was not met within the stipulated time frame, hence another World Education Forum took place in Dakar from $26^{\text {th }}-$ $28^{\text {th }}$ April 2000, and endorsed six goals with a view to, among other things;

- Ensuring that the learning needs of young people and adults are met through access to appropriate learning and life skills programmes; and

- Achieving a $50 \%$ improvement in levels of adult literacy by 2015 , especially for women, and equitable access to basic and continuing education (UNESCO, 2005).

Since education in all its ramifications is the legal right of all citizens, it is therefore imperative that those, who for whatever reason(s) are educationally disadvantaged should not be denied their inalienable right to formal education, which begins with basic literacy. In Nigeria, there are many who are yearning and yawning for opportunities to acquire literacy skills that would enhance both their living conditions and statuses. Majority of the people in this category are mainly the rural dwellers, especially the peasant farmers and some artisans and technicians in the urban areas.

The literacy situation in Africa as analysed by UNESCO in Osokoya (2008) shows that Nigeria's literacy level is 49\%, South Africa (84\%), Kenya (79\%), Cameroon (72\%) and Ghana (68\%). However, according to World Bank's report (2010), Nigeria's male adult literacy rate is $71.9 \%$, i.e., those who aged 15 and above, and who can read and write simple statement in their daily life activities. Although, the report observed that "Nigeria is one of the developed economies in Africa", but it also pointed out that "more than $50 \%$ of Nigerians live in poverty with corruption and poor infrastructure" as 
major impediments to sustainable development. It could be argued that if $71.9 \%$ of male Nigerian adults are literate, then the female adult literacy rate could be about $28.1 \%$ or more. By implication, the scourge of poverty will be felt more by majority of the women on account of illiteracy. By implication, Nigeria's literacy for both male and female may not be more than $50 \%$. This ugly scenario calls for urgent attention and quick intervention measures to drastically reduce the illiteracy rate in Nigeria, and the appropriate step to take would be to re-emphasise adult literacy with renewed vigour and practical actions.

This paper attempts some conceptual clarifications, a brief foray into the historical antecedents of adult literacy, and it examines adult literacy vis-à-vis the National Policy on Education. The paper also highlights the need for Adult Literacy College, its problems and prospects, and make some recommendations to ensure sustainable Adult Literacy College(s) in Nigeria.

\section{Adult Literacy in Nigeria}

The history of adult literacy in Nigeria is as old as the advent of Western formal education. The European Christian missionaries and their muslim counterparts pioneered its introduction. The early missionaries introduced adult literacy as a means through which the new converts were taught how to read the Bible and sing from the hymn book. The idea was to make their converts literate in their local languages (Nwafor, 2009; 2011). Later, when the colonial government showed interest in the education, adult literacy gradually was relegated to the background.

However, in 1945 the colonial administration "embarked on ambitious adult education programmes" (Ezimah, 2004). This was bolstered through mass literacy campaigns under the leadership of E.R. Chardwick and A.J. Carpenter. The goal of this programme was to ensure that participants acquired literacy and numeracy skills. The nation-wide campaigns did not yield much results, especially in the rural areas because there were fewer adult education centres, coupled with inadequate staff and funds. It could be argued that after independence in 1960, greater attention was given to formal education of the youths. Then, came the civil war which also adversely affected the development of adult literacy. The period that followed witnessed a new consciousness in the educational development of Nigeria, especially with the formulation of the National Policy on Education in 1977.

Adult literacy is a part of the Adult Education component of the National Policy on Education (2004). The goals of Adult Education are clearly spelt out, one of them is:

To provide functional literacy and continuing education for adults and youths who have never had the advantage of formal education or did not complete primary education. These include the nomads, migrant families, the disabled and other categories or groups, especially the disadvantaged gender (p.25).

But this lofty and laudable goal is yet to receive the attention it deserves. There are many illiterate adults and youths who dropped out of school, but who need opportunities to improve themselves through adult literacy programmes. Unfortunately, inadequate provisions are made in some cases, where such programmes are available, while in most cases, especially in the rural areas, adult literacy programmes are totally absent.

Again, the adult literacy component of the Universal Basic Education has been silent; nothing is being said or done about it by government. It is observed that there is general apathy towards the implementation of adult literacy programmes, because governments in the federation tend to favour formal education, but at the same time they pay lipservice to adult literacy/education. For example, the National Policy on Education (2004) provides that:

Basic education... shall also include adult and non-formal education programmes at primary and junior secondary education levels for adults and out-of-school youths (p.13).

From the above statement, it is obvious that there is need to sustain the basic literacy education the adults acquire so that they can improve themselves and contribute to the overall development of society, but the site for the inclusion of disadvantaged persons at both the primary and junior secondary school levels is non-existent in the formal school system.

\section{Conceptual Clarification}

The terms 'literacy' and 'adult literacy' have been variously defined by different scholars in different contexts. Hence conceptual clarification here is necessary. The key word here is "literacy" and as such it deserves a brief analysis that would help to give a clearer understanding of the broader term "adult literacy". 


\section{The Concept of Literacy}

In the simplest sense, literacy means "the ability to read and write" in a given language, but this definition appears very inadequate because it does not give a clear picture of the level of one's "ability to read and write". This myopic conception has led many countries to construe and apply literacy to education in different ways and contexts. For example, Sosu (2006) observes that "Albania, Djibouti, Niger, Sierra Leone, Senegal provide a definition for literacy in terms of "the capacity to read and write". In Ethiopia, it implies the "percentage of the population aged 10 and above who can read and understand a short and simple statement". In Madagascar, literacy is associated with "these who can read and write and have basic numeracy skills or those who have reached the fifth year of primary education, or higher..." In Sri Lanka, literacy simply implies the acquisition of "minimal language competence". These definitions or conceptions are not only inadequate but also vague.

For Akinpelu (2002), literacy means more than the skills or the ability to read and write alphabets, words and simple statements. This, is what Wagner (1991) calls "native or low literacy". Obanya (2004), views literacy as a developmental concept, which recognises the UNESCO's definition of literacy as the ability to read and write with understanding of a simple statement (in one's own language) related to one's daily life". Later, this definition was complemented by the "ability to count and do simple calculations (or basic arithmetic).

With time, the scope of literacy became broader to include "other illiteracies" and approaches to literacy. In recent times, we talk about computer literacy, technological literacy, environmental literacy, and so on (Akinpelu, 2002). It is in recognition of this fact, that the Programme for the International Assessment of Adult Competencies (2006) postulates that: "Literacy is the ability to identify, understand, interpret, create, communicate and compute, using printed and written materials associated with varying contexts". Literacy involves a continuum of learning which enables individuals to actualize their goals, to develop their knowledge and potential, and to take full and active part in their community and the larger society. This ultimately leads to functional literacy; i.e., the ability to adapt to new and changing circumstances and requirements. By implication, a functionally literate person must have gone beyond being "moderately literate" to being "highly literate" (Wagner, 1991).

In effect, it is the functional aspect of literacy that has motivated governments and individuals to seek ways of improving literacy rates. Some reasons for this are given by Suso (2006) as follows:

- The Right Approach: It is evident that there is a right to literacy as there is a right to education; and that a reduction in illiteracy will lead to a reduction in poverty.

- The Social Approach: This approach envisages literacy as a desired outcome that focuses on social or cultural dimensions which has a link with human development, empowerment and personal well-being.

- The Functional Approach: This approach is premised on skills and competencies one needs to function effectively in society, which encourages self-employment. The aim of this approach is to sustain economic growth and to increase productivity.

In essence, all forms of literacy and the approaches to them are geared towards making the recipients functional and selfreliant individuals, who will equally contribute meaningfully to societal development. In this regard, Jalal and Sardjunani (2006) affirm that

literacy plays an essential role in improving the lives of individuals by enabling economic security and good health and enriches societies by building human capital, fostering cultural identity and tolerance, and promoting civic participation (p.132).

\section{The Concept of Adult Literacy}

The concept of adult literacy is derived from the general concept of literacy. In other words, it is an aspect or a type of literacy that has to do with the adults. An adult in this case is someone, in the Nigerian context, who is eighteen years and above, and who is mentally, physically, socially and psychologically mature. Adult literacy therefore has to do with the ability of an individual adult (man or woman) to read, write and communicate in known language(s), as well as the ability to do basic mathematical computations far beyond basic literacy level. In simple terms, adult literacy should be seen as a tool that can equip the individual to improve himself intellectually, to empower himself economically, and to make himself socially and politically relevant.

With this tool, the mutually reinforcing trinity of poverty, illiteracy and gender inequality can be drastically reduced to the barest minimum. It is in recognition of this that Hinzen (2006) observes that: 
"Adult literacy is the fertilizer needed for development and democracy to take root and grow. It is the invisible ingredient in any successful strategy for eradicating poverty and achieving gender equality" (p.49).

In order to realize this, adult literacy should be seen as a continuous process that requires regular and sustained learning. This, unarguably forms the basis of functional adult literacy that would ensure life-long learning process, which is opposed to adult literacy that enslaves" (Obanya, 2004).

\section{Components of Adult Literacy Programme}

The adult literacy programme that would ensure functionality has the following components:

- $\quad$ Reading; i.e., ability to read up to a particular grade level;

- Writing; i.e., the ability to write clearly and reasonably in a particular language;

- Mathematics: "Numeracy" or the ability to perform basic mathematical operations needed in daily life.

- English as a second or other language (ESOL): The teaching of English speaking, listening, reading and writing skills to those for whom it not a native language.

- Cultural literacy: Familiarity with the background knowledge of the cultural heritage of one's society.

Adult literacy programme can be categorized into two: basic adult literacy and functional adult literacy programmes (Ezimah, 2004). The Basic Adult Literacy Programme is mainly designed to arm or furnish the students with the rudimentary skills of reading, writing and computation through the use of the local languages, especially in the mother tongue. The objective here is to equip the learners with basic skills of communication and understanding of their environment. On the other hand, functional adult literacy programmes combine both the teaching of literacy, numeracy and vocational skills. The objective is to equip recipients with skills and knowledge that could make them employable and useful in other spheres of life on completion of training. For this reason, adult literacy learning programmes should take place in the context of development or livelihood activities. In this respect, Hinzen (2006) postulates that:

"... literacy can best be learned by adults through a highly contextual, even individualised programme in which the literacy learners are engaged in doing their own daily life literacy activities - "learning by doing" rather than "learning in preparation for doing", or... "breaking out of the education silo into ..." a "literacy second" model, a programme starting with a developmental activity and including informal literacy learning within it" (p.55).

This type of adult literacy makes the participants useful to themselves as well as to the larger society. In effect, adult literacy programme should not take a single model, rather it should be diversified. It could be argued that a "one-size-fitsall programme" can be a recipe for failure.

\section{Rationale for Adult Literacy in Nigeria}

The reasons for greater emphasis on adult literacy at present are glaring, especially with the global attention and policy statements encapsulated in Millennium Development Goals (MDGs) and the Education for All (EFA) goals. It is evident the adult citizens are more actively involved in national development, transformation agenda and the Millennium Development Goals (MDGs). Hence, this category of citizens deserves serious attention so that they cannot only contribute to the socio-economic and political growth of the country, but also to improve their welfare and life expectancy. In addition, most adults are parents; their level of education undoubtedly will influence positively or negatively the quality and level of education their children would attain.

Furthermore, literacy is often related to health matters, especially such issues like preventive health and maintaining health, pre-natal and post-natal health (infant care), public health, and so on. In essence, the quality of literacy services available will in turn improve the quality of life. For example, the quality of adult literacy recipients get would be manifested in their occupational activities, e.g., agriculture, trades like tailoring, carpentry, co-operative activities, etc.

Moreover, adult literacy programmes where it is well-planned and effectively implemented would motivate knowledge - hungry adults to aspire to greater heights in academics and vocational training; a situation that ultimately engenders lifelong education. The literacy programmes could ensure the achievement of larger community initiatives, and equally serve as a component of an all-out attack on poverty and other social conditions that result in undesirable community problems. Finally, adult literacy could help its recipients to be gainfully employed and earn higher income and higher status. In fact, it will help its beneficiaries to make use of the computer, internet and e-mail for more information and connections. 


\section{The Need for Adult Literacy College}

Since the dawn of the $21^{\text {st }}$ century, the Nigerian educational system has been witnessing landmark reforms, and the idea of establishing Adult Literacy College will be a monumental one. In fact, it is no exaggeration to say that it is only Adult Literacy/Education that is yet to have a post-primary institution that could help the adult literacy recipients to continue their education up to "junior secondary education level" (NPE, 2004), and even beyond.

Education in all forms is a continuous process, which begins from the womb and ends in the tomb, and as such adult learners who have acquired basic literacy skills should not stagnate at any stage of the educational process. Hence, establishing Adult Literacy College would bridge the yawning gap that had existed for too long, and would provide many the opportunities they longed for, especially those who dropped out of school. Secondly, the proposed Adult Literacy College will add the needed impetus to achieving two of the Dakar 2000 Education for All (EFA) goals already mentioned earlier in this paper. Undoubtedly, the Adult Literacy College will address the needs of young people and adults, and will also provide them access to appropriate learning and life skills programmes, as well as improve adult literacy especially for women, who have been marginalized in educational provisions for too long as a result of cultural encumberances.

The establishment of an Adult Literacy College will provide avenues for socio-economic and political empowerment of its recipients. It is expected that the students will acquire some essential inputs in their empowerment process. The inputs include knowledge, skills, self awareness, visible tools of power, positive self-concept, and full involvement/full control (Obanya, 2004). Empowerment here therefore implies functional literacy in practice, which gives the individual beneficiaries a sense of self-worth, self-reliance and personal autonomy. In essence, the impact of the empowerment will, no doubt, be felt in the growth of the Gross National Product (GNP), and in the increased per capita income of individual citizens.

\section{Problems and Prospects of Adult Literacy College}

It would be an illusion to think that the envisioned Adult Literacy College will come on stream hitch-free. Certainly, it will have some teething problems, since it has not been experimented anywhere in Nigeria before now.

Prominent among the problems the college will encounter is inadequate resources that would ensure quality adult literacy learning programmes. There are three aspects of resources here: human, physical and financial. Human resources include administrators, supervisors, facilitators (teachers), etc., while physical resources refer to facilities, equipment, etc., needed for the success of the programme. Financial resources imply funding and the sources of generating funds for adult literacy programmes. Again, lack of political will and commitment on the part of government would lead to non-implementation and/or completion of some of the lofty projects. In this case, government has no moral justification to abandon her financial responsibilities, for whatever reason, in making adequate financial provisions for the Adult Literacy College. Other stakeholders such as non-governmental organisations and public-spirited individuals can only participate effectively when government blazes the trail.

In addition, learners' participation in the adult literacy programmes of the college could be another problem. The learners' participation is very crucial to the successful implementation of the proposed college and the realization of its goals and objectives. The learners may be constrained by some factors such as distance, domestic responsibilities, nature of employment (for those already employed), accommodation (for those who would prefer to live outside the college), etc. All these to a large extent will determine the degree of learners' participation, which is critical to the actualization of adult literacy programmes.

On the other hand, the proposed Adult Literacy College, when established, in spite of the daunting challenges it might face, has some advantages to be derived from it. In the first instance, if properly staffed and equipped, coupled with activities that meet the needs of the adult learners, it will arm the recipients with both cognitive and psycho-motor skills with which to fight poverty. In other words, the proposed college will assist in poverty eradication or alleviation. In addition, empowering the adult learners will not be limited to literacy and vocational skills, it is expected that the curriculum will have integrated learning experiences, which will include inculcation of desirable behavioural patterns and attitudes expected of good citizens. In effect, the proposed College would provide an avenue for training learners for effective citizenship. Finally, the proposed College would not lose sight of the global emphasis on women education. As a result, the adult literacy programmes here must not be dominated by male-oriented ones, rather efforts should be made to ensure gender parity in consonance with the goals of Education For all (EFA) already mentioned above. 


\section{Conclusion}

From the foregoing, it is evident that if no concerted efforts are made to provide "a second chance", opportunity to many who do not have the opportunity of being literate in the real sense, many people will suffer many disabilities, especially the rural dwellers who wallow in abject poverty. The women folk may also continue in their status as "second class citizens". Hence, adult literacy programmes of the proposed college should be diversified to accommodate an allinclusive and integrated learning experiences that would make functionality the central focus and objective of all activities of the institution.

\section{Recommendations}

The success of the proposed Adult Literacy College will depend so much on government, staff (facilitators), voluntary agencies, and the students.

In the first place, government should take the lead in the responsibility of providing trained and qualified teachers/facilitators as well as other supporting staff. It should ensure that this idea does not suffer the fate of "abandoned projects" as a result inadequate funding and lack of foresight.

Again, the Adult Literacy College should be properly backed up by government legislation and well formulated policy that would spell out in clear terms the roles and expectations of the institution. In addition, government should, as a matter of necessity, invest in ongoing feedback and evaluation mechanisms, data systematisation and research.

Furthermore, teachers/facilitators, on the one hand, should be given substantial initial training and regular retraining courses, and be exposed to opportunities for professional development. On the other hand, learners should be actively motivated through the use of a wide range of participatory methods, and through addressing issues of relevance to their lives.

Importantly, to ensure sustainability, government should dedicate 3\% of her annual budget for education to adult literacy. This can stimulate the interests of local and international donor agencies that might want to partner with her in this project. Therefore, in order to rekindle interest in adult literacy, vigorous national mass literacy campaigns should be embarked upon using the mass media and other relevant agencies. Finally, the Federal Government should as a matter of priority and policy, float a pilot scheme of one Adult Literacy College in each of the six geo-political zones of Nigeria.

\section{References}

Akinpelu, J.A. (2002). Philosophy and Adult Education. Ibadan: Sterling-Horden Publishers (Nig.) Ltd.

Ezimah, M. O. A. (2004). Knowing Adult Education: Its Nature, Scope and Processes. Owerri: Springfield Publishers Ltd.

Federal Republic of Nigeria (2004). National Policy on Education. Lagos: NEDRC.

Hinzen, H. (2006). "Resourcing for Quality: Adult Literacy Learning". In Hinzen H. (ed.) Adult Education and Development. 66(45-64).

Iwe, N.S.S. (1978). "Universal Fundamental Human Rights." In Christianity, Culture and Colonialism in Africa. Port Harcourt: Rivers State Newspapers Corporation.

Jalal, F. \& Sardjunani, N. (2006). "Increasing Literacy in Indonesia". In Adult Education and Development. 67(131-158).

Nwafor, N.H.A. (2009). An Introduction to History of Education. Port Harcourt: Dot Solutionz Printers \& Publishers.

Nwafor, N.H.A. (2011). A Handbook on Policy and Design. Port Harcourt: Dots Solutionz Printers \& Publishers.

Nzeneri, I. S. (2010). Adults in Battle: Any Hope of Victory? Inaugural Lecture; University of Port Harcourt.

Obanya, P. (2004). The Dilemma of Education in Africa. Ibadan: Heinneman Educational Books (Nig.) Plc.

Osokoya, I. O. (2008). Contemporary Issues in Educational History and Policy in Nigeria. Ibadan: Laurel Educational Publishers Ltd.

Programme for the International Assessment of Adult Competencies (2006). http:www.oeed.org/ educationaeconomyandsociety/adultliteracy.htm. Retrieved 29/10/2012.

Suso, E. (2006). "An analysis of the Place of Literacy in Poverty Reduction Strategy Papers". In Hinzen, H. (ed.) Adult Education and Development. 66(239-22).

UNESCO (2003). Education For All. http://www.unesco.org/education/efareport In Association for the Development of Education in African Newsletter, 15(2-3), 10.

UNESCO (2005). "Education For All Goals and Millennium Development Goals". Site internet de I'UNESCO, www.unesco.org/education/efa/fr In Barka, L.A.B. \& Sossou, B. Education For All in Africa. Dakar: Pole de Dakar, p.294.

Wagner, D. A. (1991). "Literacy: Developing the Future”. In UNESCO, International Yearbook of Education, XLIII (79-80).

World Bank Report (2010). http://www.tradingeconomies.com/nigeria/literacy-rate-adult-make-percent-ofmales-ages-15-andabove-webdata.htmol. Retrieved 29/10/2012. 